Bernadette Sangmeister

\title{
DEPORTATION ON THE BASIS OF DIPLOMATIC ASSURANCES
}

\section{- PERMISSIBLE UNDER THE EUROPEAN CONVENTION ON HUMAN RIGHTS?}

\begin{abstract}
A Critical Analysis of the Judgment of the ECtHR in Abu Qatada $v$ the United Kingdom (2012) and its Impact on the Jurisprudence of the ECtHR
\end{abstract}

Research Paper

LAWS 545: Comparative Counter-Terrorism Law

FACULTY OF LAW

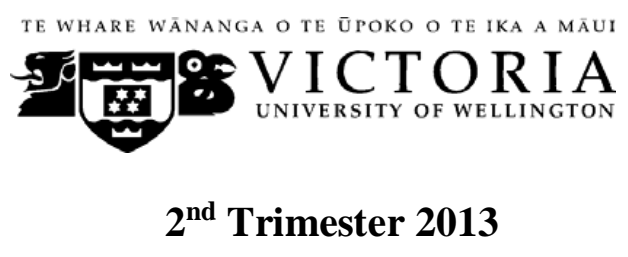


Abstract iiii

I INTRODUCTION 5

II POLICY OF DEPORTING NON-NATIONAL TERRORIST SUSPECTS

WITH DIPLOMATIC ASSURANCES 6

A Characteristics of the DWA Policy 6

1 Definition of Diplomatic Assurances 6

$2 \quad$ Classification of Diplomatic Assurances 7

$\begin{array}{ll}B & \text { Main Problems of the DWA Policy } \\ \end{array}$

$1 \quad$ Scepticism about the Reliance on Diplomatic Assurances 8

2 Creation of Inequality in the Receiving State 9

C Legal Framework of the DWA Policy 9

III EUROPEAN CONVENTION ON HUMAN RIGHTS AS A LEGAL CONSTRAINT ON THE DWA POLICY 10

A Relevant Articles with regard to the DWA Policy 10

B Analysis of the Relevant Articles $\quad 11$

$1 \quad$ Article 3 of the Convention $\quad 11$

$2 \quad$ Article 6 of the Convention 12

$3 \quad$ Other Relevant Articles of the Convention 12

IV JUDGMENT OF THE ECTHR IN ABU QATADA V THE UK (2012) 13

$\begin{array}{lll}A & \text { Principal Facts of the Case } & 13\end{array}$

$1 \quad$ DWA Order for Abu Qatada 13

$2 \quad$ National Appeals after the DWA Order 13

B Ruling of the ECtHR Concerning the Interplay of the DWA Policy and the Convention 14

$1 \quad$ Article 3: Prohibition of Torture 14

(A) Concrete Reasoning 14

(AA) Judgment of the ECtHR 14

(AAA) General Concerns about the Reliability of the MOU 15

(BBB) Concrete Concerns about the Meaning and Operation of the MOU 16

(CCC) Finding: No Violation of Article 3 
(BB) Evaluation of the Concrete Reasoning

$\begin{array}{ll}\text { (B) General Principles } & 17\end{array}$

(AA) Judgment of the ECtHR 17

(BB) Evaluation of the General Principles 18

$2 \quad$ Article 6: Right to a Fair Trial 19

(A) Concrete Reasoning 19

(AA) Judgment of the ECtHR 19

(AAA) Real Risk of the Admission of Torture Evidence 19

(BBB) Flagrant Denial of Justice 20

(CCC) Finding: Violation of Article 6

(BB) Evaluation of the Concrete Reasoning 21

(B) General Principles 22

(AA) Judgment of the ECtHR 22

(BB) Evaluation of the General Principles 23

$3 \quad$ Other Convention Rights 24

V IMPLICATIONS OF THE ECTHR'S JUDGMENT IN ABU QATADA 24

A Impact on the Non-Refoulement Principle 25

B Shift in Jurisprudence?

VI CONCLUSION 26

BIBLIOGRAPHY 28 


\section{Abstract}

Inspired by the recently concluded litigation seeking to deport the radical Islamic preacher Abu Qatada from the UK to Jordan, this paper aims at examining the 2012 judgment of the ECtHR by focusing on the question under which circumstances a deportation with diplomatic assurances (DWA) may be permissible under the European Convention on Human Rights.

Relevant background information will be provided concerning the interplay of the use of the DWA policy and the European Convention on Human Rights as well as concerning the particular circumstances that led to the ECtHR's ruling in Abu Qatada. In the following analysis of the judgment, the focus will be on the interplay of the DWA policy and the European Convention on Human Rights with special regard to art 3 and art 6 of the Convention. Finally, the impact of this judgment on the future jurisprudence and the DWA policy will be shown.

In the light of this judgment, it will be argued that the counter terrorism means of deporting a non-national terrorist suspect with diplomatic assurances seems to be compatible with the Convention if the diplomatic assurances given guarantee a sufficient protection of the human rights of the transferee, which due to the uncertain effects of the DWA policy, still has to be decided on a case-by-case basis.

\section{Word length}

The text of this paper (excluding abstract, table of contents, footnotes and bibliography) comprises 8234 words.

\section{Subjects and topics}

\section{Counterterrorism Law}

Deportation with diplomatic assurances

European Convention on Human Rights (Prohibition of torture, Right to a fair trial) 
"We need to stop the abuse of human rights law. The Brighton Conference [...] will examine how to reform the European Court."1

This oral statement was made by the British Home Secretary Theresa May to Parliament in the wake of the 2012 decision of the European Court of Human Rights (ECtHR) in Abu Qatada $v$ the $U K^{2}$, not only underlining the strong frustration of the British government concerning that ruling, but also calling into question the legitimacy of the ECtHR.

The judgment referred to concerned the deportation of the non-national terrorist suspect Abu Qatada ${ }^{3}$ from the UK to Jordan on the basis of diplomatic assurances against torture and other human rights violations. The ECtHR found that his deportation would not be compatible with the European Convention on Human Rights (the Convention) ${ }^{4}$, namely with art 6 of the Convention. With this judgment, the Court established a new, unprecedented ground upon which a deportation is blocked in this field of national security.

The British government strongly criticised this judgment and more generally the burden the Convention poses on its national security decisions. Demanding for greater deference of the ECtHR to national security decisions, ${ }^{5}$ they initiated the Brighton Conference where the Committee of Ministers of the Council of Europe considered the future of the ECtHR. ${ }^{6}$ Furthermore, in this context, a discussion arose even about the question if the UK should withdraw from the Convention, ${ }^{7}$ an option which the British Home Secretary acknowledged to be worth considering. ${ }^{8}$

In the end, after the UK had finally been able to deport Abu Qatada on the grounds of further assurances from Jordan, it was the same British Home Secretary who stated she was "immensely proud" that the UK was able to deport Abu Qatada in line with the Convention and the aforementioned ECtHR's ruling. ${ }^{9}$

Inspired by these recently expressed controversial views on the role of the Convention and the jurisprudence of the ECtHR in national security matters, this paper aims at examining the 2012's judgment of the ECtHR in Abu Qatada $v$ the UK by focusing on the question under which circumstances a deportation with diplomatic assurances (DWA) may be permissible under the European Convention on Human Rights.

\footnotetext{
1 (17 April 2012) 543 UKPD (HC) 174.

${ }^{2}$ Othman (Abu Qatada) v The United Kingdom (2012) 55 EHRR 1 (Section IV, ECHR) (Abu Qatada v the UK).

${ }^{3}$ His real name is Omar Mahmoud Mohammed Othman.

${ }^{4}$ Convention for the Protection of Human Rights and Fundamental Freedoms [1950] COETS 1 (adopted 4 November 1950, entered into force 3 September 1953).

${ }^{5}$ See Harlan Grant Cohen “International Law’s Erie Moment“" (2013) 34 Mich J Int'1 L 249 at 288.

${ }^{6}$ Result: Brighton Declaration (20 April 2012), in which the principle of subsidiarity of the ECtHR is highlighted, see paras 3 and 12 of the Declaration, available at <wcd.coe.int>.

${ }^{7}$ See Harlan Grant Cohen, above n 5, at 287.

${ }^{8}$ See (8 July 2013) 566 UKPD (HC) 24.

${ }^{9}$ (8 July 2013) 566 UKPD (HC) 23.
} 
In parts II and III, relevant background information will be provided concerning the interplay of the use of the DWA policy and the European Convention on Human Rights. On this basis, the aforementioned ECtHR's judgment will be examined in part IV. After having outlined the particular circumstances that led to the ECtHR's ruling of Abu Qatada, I will critically analyse the findings of the Court with special regard to the rulings on art 3 and art 6 of the Convention. In part V, the impact of this judgment on the future jurisprudence and the DWA policy will be shown. Finally, a general conclusion will be drawn (VI).

\section{Policy of Deporting Non-National Terrorist Suspects with Diplomatic Assurances}

The policy of deporting non-national terrorist suspects with diplomatic assurances (DWA policy) is one of the current approaches of European Council member states that intend to contribute to their national security. ${ }^{10}$ They use diplomatic assurances to ensure the deportation of these unwanted individuals to their home country, where the practice of torture or other inhumane treatment is common, a circumstance which engages the human rights responsibility of the sending state. ${ }^{11}$

In the UK, the DWA policy was highly promoted by the UK government as a means of treating foreign terrorist suspects ${ }^{12}$ after the Belmarsh decision of the House of Lords in $2004^{13}$, which prohibited the (indefinite) detention of non-national terrorists as being disproportionate and discriminatory.

\section{$1 \quad$ Definition of Diplomatic Assurances}

In the context of counter-terrorism law diplomatic assurances are described as "diplomatic 'promise[s]', given by the receiving state to the sending state, that the transferee will not be subjected to torture or cruel, inhuman or degrading treatment" 14 and will not be treated in breach of other human rights obligations upon return ${ }^{15}$. Accordingly, diplomatic assurances are conceived as bilateral agreements between states committing the receiving state to observing the human rights of certain individuals after their removal to that state, particularly the right not to be tortured.

The question is whether the diplomatic assurances constitute legally binding promises or not. With reference to the International Court of Justice some scholars argue that these assurances

\footnotetext{
${ }^{10}$ Abu Qatada v the UK, above n 2, at $[184 ; 186]$.

${ }^{11}$ See [185].

${ }^{12}$ See Clive Walker "The Treatment of Foreign Terror Suspects" (2007) 70 Mod L Rev 427 at 432 et seq.

${ }^{13}$ A (FC) and Others (FC) v The Secretary of State for the Home Department [2004] UKHL 56, [2005] 2 WLR 87 (Belmarsh).

${ }^{14}$ Frank Seier "Diplomatic Assurances Against Torture: Impermissible Inter Se Modifications of Erga Omnes Obligations" (LLM Thesis, University of Toronto, 2008) at 1.

${ }^{15}$ Jennifer Tooze "Deportation with Assurances: the Approach of the UK Courts" [2010] P.L. 362 at 376.
} 
form international treaties or at least an "international equivalent of the doctrine of promissory estoppel"16 since they presume an intention of the states to create legally binding obligations. ${ }^{17}$ However, the majority of the scholars argue in line with the UN High Commissioner for Human Rights that diplomatic assurances form mere promises from the receiving state, since they are created on a diplomatic level, and are therefore not legally binding. ${ }^{18}$ The latter view is convincing since diplomatic assurances are labelled as a "diplomatic" means and therefore require no act of transformation into domestic law as international treaties normally do. Thus, they cannot be presumed to express the intention of the states to create legally binding obligations. ${ }^{19}$ Therefore, they merely constitute non-legally binding bilateral agreements, which are consequently legally not enforceable.

Diplomatic assurances vary from simple oral promises to written documents. ${ }^{20}$ According to the International Centre for Counter-Terrorism in the Hague, on a written basis, three main types of diplomatic assurances can be found, namely diplomatic notes, exchange of letters and Memoranda of Understanding (MoUs), which are classified as being either "hard" or "soft" depending on whether enforcement mechanisms are provided for by the diplomatic assurances or not. ${ }^{21}$ Whereas diplomatic notes and exchanges of letters only outline promises of one state towards another, and may therefore only be signed by the state demanding or expressing that intent, a MoU must be signed by both states to form a valid agreement.

"Hard" diplomatic assurances "tend to provide enforcement mechanisms [...] and documents may be declassified". ${ }^{22}$ Enforcement is given through concrete and detailed assurances whereby the receiving state promises to treat the returning person humanely, as well as through the establishment of practical instruments, like independent monitoring bodies, which force the receiving state to abide by the assurances. ${ }^{23}$ The UK's MoU with Jordan, ${ }^{24}$ which became relevant in the case of Abu Qatada, must be conceived as a "hard" diplomatic assurance.

\footnotetext{
16 Martin Jones "Lies, Damned Lies and Diplomatic Assurances: The Misuse of Diplomatic Assurances in Removal Proceedings" (2006) 8 Eur J Migration L 9 at 29.

${ }^{17}$ Georg Noll "Diplomatic Assurances and the Silence of Human Rights Law" (2006) 7 MJIL 104 at 114.

${ }^{18}$ See generally Lena Skoglund "Diplomatic Assurances Against Torture - An Effective Strategy?: A Review of Jurisprudence and Examination of the Arguments" (2008) 77 Nordic J Int'l L 319 at 335 et seq.

${ }^{19}$ See e.g. view of the Jordanian government on the MoU with the UK, Omar Othman (aka Abu Qatada) $v$ Secretary of State for the Home Department, [2007] UKSIAC 15/2005 (26 February 2007) February 2007 at [180] (Abu Qatada v SSHD).

${ }^{20}$ Lena Skoglund, above n 18, at 334.

${ }^{21}$ Bibi van Ginkel and Federico Rojas "Use of Diplomatic Assurances in Terrorism-related Cases: In Search of a Balance Between Security Concerns and Human Rights Obligations“ (2011) ICCT <www.icct.nl> at 2.

${ }^{22}$ Ibid.

${ }^{23}$ Another enforcement mechanism can be seen in the ratification of the right of the individual to petition to the UN Committee Against Torture (art 22 UNCAT) in the receiving state, see Abu Qatada v the UK, above $\mathrm{n} 2$, at [169].

${ }^{24}$ Memorandum of Understanding Between the Government of the United Kingdom of Great Britain and Northern Ireland and the Government of the Hashemite Kingdom of Jordan Regulating the Provision of Undertakings in Respect of Specified Persons Prior to Deportation (signed 10 August 2005), available at <www.gov.uk> (MoU UK-Jordan).
} 
"Soft" diplomatic assurances "tend to lack enforcement mechanisms and are often kept confidential". ${ }^{25}$ They often constitute a mere framework agreement for obtaining assurances. In the case of Abu Qatada, not all assurances given by the Jordanian state were included in the MoU due to constitutional reasons of Jordan. Thus, a "soft" diplomatic assurance was also given by the Jordanian government, promising that they would not use the death penalty. ${ }^{26}$

\section{B Main Problems with the DWA Policy}

The DWA policy is highly contested. ${ }^{27}$ Overall, the use of diplomatic assurances as a counterterrorism instrument has been criticised as "a political strategy of uncertain worth." 28 There are two main problems of the DWA policy, arising from the uncertain effect they create.

\section{$1 \quad$ Scepticism about the Reliance on Diplomatic Assurances}

The first problem is the scepticism about whether diplomatic assurances can be relied upon. Since they are conceived as non-legally binding agreements, it has been argued that they are legally not enforceable and thus do not provide for an adequate protection of the returning person. ${ }^{29}$ Various human rights organisations ${ }^{30}$ question the reliability of "paper promises from torturers". ${ }^{31}$ Why should these diplomatic assurances be relied upon when they result from breaches of multilateral human rights obligations in the first place?

In this context, it is noteworthy that even the Commissioner for Human Rights of the Council of Europe stated in his "viewpoint" in 2006 that diplomatic assurances were "pledges" which were "not credible" and which had "turned out to be ineffective in well-documented cases". 32 Case studies about the treatment of foreign terrorist suspects after their removal to the receiving state show that the odds of torture after a DWA are high. ${ }^{33}$

Against this scepticism, it has been argued that it is the bilateral nature of the assurances which could strengthen the reliability. The promoters of diplomatic assurances underline that in contrast to multilateral obligations - diplomatic assurances form "promises that the

\footnotetext{
${ }^{25}$ Bibi van Ginkel and Federico Rojas, above n 21, at 2.

${ }^{26}$ See side letter of the British Embassy in Amman to UK's MoU with Jordan of 10 August 2005, which together with the government of Jordan's formal response- forms an exchange of letters on the use of the death penalty, available at <www.gov.uk>.

${ }^{27}$ For an overview about the problematic issues concerning the use of diplomatic assurances in counter-terrorism law see generally Kate Jones "Deportations with Assurances: Addressing Key Criticisms" (2008) 57 ICLQ 183.

${ }^{28}$ Martin Jones, above n 16, at 15.

${ }^{29}$ See Ben Middleton "Deporting Terrorist Suspects with Assurances: Lessons from the United Kingdom" (2012) 12 Conn Pub Int LJ 127 at 164 et seq.

${ }^{30}$ See e.g. Amnesty International “Dangerous Deals: Europe's Reliance on 'Diplomatic Assurances' Against Torture (12 April 2010) <www.amnesty.org> or Human Rights Watch "Still at Risk: Diplomatic Assurances No Safeguard Against Torture" (15 April 2005) <www.hrw.org>.

${ }^{31}$ Kent Roach Comparative Counter-Terrorism (Cambridge University Press, New York, 2011) at 288.

32 Thomas Hammarberg "Torture can never, ever be accepted" (27 June 2006) in 2006 Viewpoints Commissioner for Human Rights <www.coe.int>.

${ }^{33}$ E.g. nearly a hundred per cent "chance" of deported persons being subjected to torture from the U.S. under the Bush administration until 2005, see Katherine Hawkins "The Promises of Torturers: Diplomatic Assurances and the Legality of "Rendition"” (2006) 20 Geo Immigr LJ 213 at 264.
} 
rendition of the subjected person is without prejudice to the human rights promise of the multilateral treaties" 34 and provide greater protection to deportees because of the more direct nature of the agreement. ${ }^{35}$

Even if this seems possible in cases where extremely strong bilateral ties between the receiving and the sending state exist, the reliability on assurances given by countries which constantly breach multilateral human rights obligations remains a controversial issue of the DWA policy.

Even in the case where the diplomatic assurances are abided by in the receiving state, another problem arises, namely the creation of inequality in the receiving state concerning the different treatments of criminal suspects - the ones under the authority of a diplomatic assurance and those without them. That is the reason why it is controversial if or to what extent DWA policy states, effectively condone inequality and systemic problems in these countries by allowing for assurances. ${ }^{36}$

Against this scepticism, governments using the DWA policy bring up the argument that their policy does not undermine but strengthen the goal of improving human rights standards in the receiving country as they increasingly address detention issues. ${ }^{37}$

It has to be questioned if such a positive effect can really be achieved in the receiving state. Nevertheless, it would be perverse to insist on "equality of law" in the receiving state where the sending state has not only the possibility but also the legal obligation to insist on rights to the benefit of an individual, the deportee.

\section{Legal Framework of the DWA Policy}

First of all, it must be noted that the power to deport stems from immigration law. For instance in the UK, section 3(5)(a) of the Immigration Act 1971 allows the Secretary of State to deport non-nationals if the deportation is conducive to the public good. ${ }^{38}$ The risk a nonnational person poses to national security has been seen as a sufficient reason for deportation. $^{39}$

However, the policy of using DWAs is limited by legal constraints under the sending state's human rights obligations both on an international and European level. ${ }^{40}$ The internationally acknowledged principle of non-refoulement is of particular importance in this context. It

\footnotetext{
${ }^{34}$ Georg Noll, above n 17, at 123.

${ }^{35}$ Abu Qatada v SSHD, above n 19, at [495].

${ }^{36}$ See Kate Jones, above n 27, at 193.

${ }^{37}$ Ibid.

${ }^{38}$ Immigration Act 1971 (UK), s 3(5)(a).

${ }^{39}$ See Jennifer Tooze, above n 15, at 364 et seq.

${ }^{40}$ At 366.
} 
stipulates that individuals are protected against removal to a country where their lives or freedoms are threatened. ${ }^{41}$ On an international level, this principle can be found explicitly in art 33 of the Refugee Convention ${ }^{42}$ and implicitly, developed by the jurisprudence under general prohibitions of torture, ${ }^{43}$ e.g. under art 7 of the ICCPR ${ }^{44}$. On a European level, the non-refoulement principle has been developed under art 3 of the Convention.

\section{European Convention on Human Rights as a Legal Constraint on the DWA Policy}

In how far does the Convention function as a legal constraint on the DWA policy? What is the scope of protection of the non-refoulement principle under the Convention?

Before the decision of Abu Qatada in 2012, the ECtHR has discussed the following articles in the context of the DWA policy, which guarantee either substantial or procedural rights: ${ }^{45}$

- Art 2: Right to life

- Art 3: Prohibition of torture

- Art 5: Right to liberty and security

- Art 6: Right to a fair trial

- Art 13: Right to an effective remedy

- Art 34: Right of individual petition

First of all, it is noteworthy that art 34, the right of individual petition, forms part of section II ("European Court of Human Rights") of the Convention, whereas the other rights listed above form part of section I ("Rights and Freedoms") of the Convention.

Under section I of the Convention, art 15 is of particular importance. According to art 15, arts 2 and 3 of the Convention cannot be derogated from in times of emergency and are therefore absolute in contrast to the other rights listed above. ${ }^{46}$ Thus, these absolute rights pose a greater legal constraint on the DWA policy than the others do. Accordingly, the threshold of violating them is lower than the one of relative rights, like of arts 5 and 6 . Nonetheless, according to the jurisprudence of the ECtHR, these relative rights are violated in a "foreign case" 47 if the

\footnotetext{
${ }^{41}$ Cornelis (Kees) Wouters "Reconciling National Security and Non-Refoulement: Exceptions, Exclusion, and Diplomatic Assurances" in Ana Maria Salinas de Frias, Kathja LH Samuel and Nigel D White (ed) CounterTerrorism: International Law and Practice (Oxford University Press, Oxford, 2012) 579 at 580.

421951 Convention Relating to the Status of Refugees 189 UNTS 137 (adopted 28 July 1951, entered into force 22 April 1954) (Refugee Convention).

${ }^{43}$ Cornelis (Kees) Wouters, above n 14, at 580.

44 International Covenant on Civil and Political Rights 999 UNTS 171 and 1057 UNTS 407 (opened for signature 16 December 1966, entered into force 23 March 1976) (ICCPR).

${ }^{45}$ Based on the factsheet of the ECtHR on expulsion and extradition cases of July 2013, comprising the relevant jurisprudence of the ECtHR from 1989 until July 2013, available at <www.echr.coe.int>.

${ }^{46}$ Art 2 can exceptionally be derogated from in the case of deaths resulting from lawful acts of war, see art 15 (2) of the Convention.

${ }^{47}$ Meaning a deportation case where the receiving state is not a High Contracting Party to the Convention.
} 
deportation constitutes a "flagrant denial" of these individual's Convention rights, ie "a complete nullification of the right $[\mathrm{s}]$ ". 48

\section{B Analysis of the Relevant Articles 49 \\ $1 \quad$ Article 3 of the Convention}

Art 3 of the Convention provides: ${ }^{50}$ "No one shall be subjected to torture or to inhuman or degrading treatment or punishment".

On a literal reading, art 3 contains no explicit prohibition of removing a person to torture. However, the ECtHR held in the landmark case Soering $v$ the United Kingdom ${ }^{51}$ in 1989 that article 3 is violated where substantial grounds have been shown for believing that an extradition exposes the returning person to a real risk of torture, inhumane or degrading treatment or punishment in the receiving state. ${ }^{52}$ This principle was further developed in Chahal $v$ the United Kingdom ${ }^{53}$ in which the ECtHR explicitly stated that this principle is also applicable with regard to deportations of foreign terrorist suspects since art 3 is absolute and forbids any derogation so that even national security reasons cannot be balanced against it. ${ }^{54}$ Therefore, art 3 of the Convention renders deportations unlawful if there is a real risk of torture or ill-treatment.

This line of reasoning has been confirmed in a number of judgments by the ECtHR until at present. ${ }^{55}$ In Saadi $v$ Italy ${ }^{56}$ the court clarified that this liability of the removing state occurred under the Convention "by reason of its having taken action which has a direct consequence on the exposure of an individual to the risk of proscribed ill-treatment". ${ }^{57}$

Until its judgment in Abu Qatada v the $U K$ in 2012, the ECtHR had been reluctant to accept the DWA policy and had always found this article violated, ruling in each case that the assurances given could not remove the real risk of torture or ill-treatment in the receiving state..$^{58}$

\footnotetext{
${ }^{48}$ See Jennifer Tooze, above $\mathrm{n} 15$, at 367.

${ }^{49}$ Since Art 3 and 6 of the Convention were of particular importance in the decision of Abu Qatada v the UK, these two articles will be examined first and in more detail than the other articles.

${ }^{50}$ Above $\mathrm{n}$ 4, art 3.

${ }^{51}$ Soering $v$ the United Kingdom (1989) 11 EHRR 439 (ECHR) (Soering $v$ the UK).

${ }^{52}$ At [91].

${ }^{53}$ Chahal $v$ the United Kingdom (1996) 23 EHRR 413 (ECHR) (Chahal $v$ the UK).

${ }^{54}$ At [75-82]. Different view expressed in the dissenting judgment by the minority of the Court, which indicated that the prohibition of torture was not absolute in its "extra-territorial application", see "Joint Partly Dissenting Opinion Gölcüklü, Matscher, Sir John Freeland, Baka, Mifsud, Bonnici, Gotchev and Levits" at [1].

${ }^{55}$ See e.g. $D v$ the United Kingdom (1997) 24 EHRR 423 (ECHR); Mamatkulov and Askalov v Turkey (2005) 41 EHRR 2 (Grand Chamber, ECHR) (Mamatkulov and Askarov v Turkey); $N$ v Finland (2005) 43 EHRR 12 (Section IV, ECHR).

${ }^{56}$ Saadi v Italy (2008) 49 EHRR 730 (Grand Chamber, ECHR) at [126] (Saadi v Italy).

${ }^{57}$ At [126].

${ }^{58}$ See e,g. Chahal $v$ the UK, above n 53, at [105-107]; Baysakov and Others v Ukraine (54131/08) Section V, ECHR 18 February 2010 at [51].
} 
Art 6 of the Convention stipulates the right to a fair trial. Art 6 (1) provides as follows ${ }^{59}$ :

In the determination of his civil rights and obligations or of any criminal charge against him, everyone is entitled to a fair and public hearing within a reasonable time by an independent and impartial tribunal established by law. [...]

Furthermore, art 6 contains provisions protecting explicit fair trial rights in criminal proceedings, notably the presumption of innocence in criminal cases and other "minimum rights" for everyone charged with a criminal offence, including the right to have access to legal representation and the right to examine witnesses against himself. ${ }^{60}$

Due to the right's "prominent place in a democratic society", the ECtHR stated in Soering $v$ the United Kingdom that a breach of art 6 of the Convention was possible where the transferee had suffered or was at a risk of suffering a "flagrant denial of a fair trial" in the receiving state. ${ }^{61}$ In 2010, the ECtHR referred to this idea in Mamatkulov and Askarov $v$ Turkey, ${ }^{62}$ but made no further (substantive) clarification on that point ${ }^{63}$, leaving its relevance for DWAcases uncertain until the decision of Abu Qatada $v$ the UK.

\section{$3 \quad$ Other Relevant Articles of the Convention}

Among the other relevant articles of the Convention, art 2, the absolute right to life, is of particular importance. In H.N. v Sweden ${ }^{64}$ the court expressed that the principles established with regard to the real risk of ill-treatment under art 3 also applies in regard to art $2{ }^{65}$

By contrast, the ECtHR expressed doubts as to the reliance on art 5 (the right to liberty and security) in deportation cases. ${ }^{66}$

Besides, the procedural right of art 13 , the right to an effective remedy, has been found as applicable in deportation cases. ${ }^{67}$ In $A v$ the Netherlands ${ }^{68}$ the judges held that art 13 guarantees the "availability at the national level of a remedy to enforce the substance of the convention rights and freedoms", thus for the first time providing for an arguable complaint under a substantive provision of the Convention, like art $3 .{ }^{69}$

\footnotetext{
${ }^{59}$ Above n 4, art 6 (1).

${ }^{60}$ Above n 4, art 6 (2) and (3).

${ }^{61}$ Soering $v$ the UK, above $\mathrm{n} 51$, at [113].

${ }^{62}$ Mamatkulov and Askarov $v$ Turkey, above n 55, at [88].

${ }^{63}$ Abu Qatada v the UK, above n 2, at [284].

${ }^{64}$ H.N. v Sweden (30720/09) Section V, ECHR 15 May 2012.

${ }^{65}$ At [36].

${ }^{66}$ Tomic $v$ the United Kingdom (17873/03) Section IV, ECHR 14 October 2003 at 12 (Tomic v the UK).

${ }^{67}$ See e.g. A $v$ the Netherlands (4900/06) Section III, ECHR 20 July 2010.

${ }^{68}$ Ibid.

${ }^{69}$ At [155]. The scope of the state's obligation under art 13 therefore varies with regard to the arguable complaint, see [157].
} 
The last relevant article, art 34 of the Convention, which provides for the right of individual petition, is violated in DWA cases where the sending state fails to comply with interim measures issued by the ECtHR, thus not only preventing the court from examining the individual's complaint but also hindering the effective exercise of the individual's right. ${ }^{70}$

\section{Judgment of the ECtHR in Abu Qatada v the UK (2012)}

\section{A Principal Facts of the Case}

\section{$1 \quad$ DWA Order for Abu Qatada}

Abu Qatada, a Jordanian national and radical Islamic preacher, was recognised as a refugee in Britain in 1994 as he had suffered from torture by the Jordanian authorities before. ${ }^{71}$ In 1999 and 2000, he was convicted twice in absentia by the Jordanian state on the terror charge of conspiracy to cause explosions at different targets in Jordan, and sentenced to life imprisonment and 15 years imprisonment respectively. In both cases, evidence obtained by torture of other defendants was used. ${ }^{72}$

As a noncitizen terrorist suspect involved with al Qaeda ${ }^{73}$, on 11 August 2005, the British Secretary of State served Abu Qatada with a DWA order for national security reasons after a MoU between the governments of the UK and Jordan had been signed one day before on a British initiative. $^{74}$

The $\mathrm{MoU}^{75}$ sets out several assurances of compliance with international human rights standards, which have to be abided by when a person is returned to one State from another, including in particular concrete provisions of proper humane treatment and one more abstract provision of the right to a fair trial. ${ }^{76}$ Furthermore, the MoU provides for the right of a returning person to contact regularly an independent body in the receiving state which has been nominated by the UK and the Jordanian government. ${ }^{77}$ On this basis, the two governments agreed on the Adaleh Centre as the monitoring body. ${ }^{78}$

\section{$2 \quad$ National Appeals after the DWA Order}

Abu Qatada appealed against his deportation order to the Special Immigration Appeal Commission (SIAC), arguing that this decision was incompatible with the Convention, namely with art 2, 3, 5 and 6 of the Convention. Concerning art 3 he stated that a breach was inherent in the deportation order as he was at a real risk of torture once he would be back in

\footnotetext{
${ }^{70}$ See e.g. Mamatkulov and Askarov v Turkey, above n 55, at [128].

${ }^{71}$ Abu Qatada $v$ the UK, above n 2, at [7].

72 At [9-20].

${ }^{73}$ Belmarsh, above n 13, at [2-3].

${ }^{74}$ Abu Qatada $v$ the $U K$, above n 2, at [8 and 25].

${ }^{75}$ MoU UK-Jordan, above n 24.

${ }^{76}$ See Abu Qatada $v$ the UK, above n 2, at [77-78].

77 See [77].

${ }^{78}$ At [23-24].
} 
Jordan; concerning art 6 he submitted inter alia that his deportation to Jordan would pose him at a real risk that torture evidence would be used in his retrial, infringing his right to a fair trial. $^{79}$

SIAC dismissed the appeal of Abu Qatada. As to the complaints under art 3 of the Convention they considered that although the risk of torture for an "ordinary Islamist extremist" was real in Jordan, the MoU between the UK and Jordan and the monitoring agreement would give sufficient protection for Abu Qatada from being subjected to torture in Jordan. ${ }^{80}$ With regard to his complaints under art 6 of the Convention they held that there would be no flagrant denial of justice even if there was a real risk of the admission of torture evidence in his retrial. ${ }^{81}$

The Court of Appeal agreed on SIAC's findings on art 3, but overruled SIAC's decision with regard to a possible breach of art 6 of the Convention. ${ }^{82}$ Due to the high risk that torture evidence might be used in his retrial the court stated that explicit assurances on this point were required but had not been given by Jordan yet. ${ }^{83}$

The House of Lords reversed the Court of Appeal's findings and re-instated the original arguments put forward by SIAC that a deportation would not be a violation of any rights under the Convention. ${ }^{84}$

\section{B Ruling of the ECtHR Concerning the Interplay of the DWA Policy and the Convention}

Abu Qatada alleged before the ECtHR a violation of the Convention, particularly of art 3 and art 6 of the Convention, if he was deported to Jordan. ${ }^{85}$ On 17 January 2012, the ECtHR ruled that his deportation to Jordan with the particular MoU would not violate art 3 but his right to a fair trial under art 6 of the Convention. ${ }^{86}$

\section{$1 \quad$ Article 3: Prohibition of Torture}

(a) Concrete Reasoning

(aa) Judgment of the ECtHR

First of all, the court stated that a "culture of impunity" concerning "widespread and routine" torture was found in the Jordanian criminal system. ${ }^{87}$ Therefore, according to the judges, the deportation of a "high profile Islamist" like Abu Qatada to Jordan without any assurances

\footnotetext{
${ }^{79}$ At [25].

${ }^{80}$ At [34].

${ }^{81}$ At [46].

${ }^{82}$ See [48-52].

${ }^{83}$ See Othman (Jordan) v Secretary of State for the Home Department [2008] EWCA Civ 290, [2008] 3 WLR 798 at [49-52] (Othman v SSHD).

${ }^{84}$ Abu Qatada $v$ the $U K$, above n 2, at [53-66].

${ }^{85}$ At [3].

${ }^{86}$ The judgment of the ECtHR became final on 9 May 2012.

${ }^{87}$ Abu Qatada $v$ the UK, above n 2, at [191].
} 
from the Jordanian Government would constitute a real risk of ill-treatment and therefore be incompatible with art 3 of the Convention. ${ }^{88}$ The fact that Abu Qatada claimed that he had been tortured in former times in Jordan also constituted a relevant factor to the judges. ${ }^{89}$

However, the court stated that the assurances given by the Jordanian government in the MoU and the agreement concerning Adaleh as a monitoring body must be considered in order to answer the question if any real risk of ill-treatment of Abu Qatada could be removed. ${ }^{90}$

The approach of the court contained an evaluation of both general and specific concerns about the MoU brought up by Abu Qatada.

\section{(aaa) General Concerns about the Reliability of the MoU}

The general concerns put forward by Abu Qatada question the reliability of the MoU signed by the Jordanian government. ${ }^{91}$ Firstly, he argued that Jordan could not be relied on abiding by legally non-binding diplomatic assurances since it did not even comply with legally binding, multilateral international agreements. Secondly, he brought up that where there was a systematic problem of torture and ill-treatment no assurance could ever be relied on and even where there was a non-systematic practice of torture and ill-treatment, assurances could only be relied on in cases of the establishment of an independent, effectively working monitoring body.

The court rejected these general concerns for the reason that they could not be supported by ECtHR's case-law on assurances. Instead, the judges held the following ${ }^{92}$ :

- If a state does not comply with its multilateral obligations, the extent to which it has failed to do so is at most a factor determining whether its bilateral assurances are sufficient

- When there is a systematic problem of torture and ill-treatment in the receiving state, there is no prohibition on seeking assurances

- The general human rights situation in Jordan does not exclude accepting any assurances whatsoever from the Jordanian government

Furthermore, the court emphasised that assurances must be seen in their context. ${ }^{93}$ With regard to the MoU concluded between the UK and Jordan the judges saw the strength of the agreement in the following:

- $\quad$ Specific and comprehensive $e^{94}$

\footnotetext{
88 At [192].

${ }^{89}$ Ibid.

90 Ibid.

${ }^{91}$ See [193].

92 At [193-194].

${ }^{93}$ At [195].
} 
- Given in good faith ${ }^{95}$

- Capable of being binding to Jordan because of the strong bilateral ties between the UK and Jordan and the approval by the Jordanian King himself ${ }^{96}$

\section{(bbb) Concrete Concerns about the Meaning and Operation of the MoU}

Moreover, the Court held that various concrete concerns brought up by Abu Qatada and dealing with the meaning and operation of the special provisions of the MoU were unlikely to appear. ${ }^{97}$ According to the judges, his concern about not having access to legal advice - as a "fundamental safeguard against ill-treatment" - during interrogation period was unwarranted since it was currently protected through means contained in the $\mathrm{MoU}$ and monitoring arrangements. ${ }^{98}$ In response to Abu Qatada's concern about the capacity of the Adaleh Centre to monitor him the judges stated that although its capacity could not be equated to leading international NGOs, its subsidiary, The National Team to Combat Torture, would still provide for the necessary interdisciplinary expertise and sufficient staff. ${ }^{99}$ The judges added that a certain independence of the body, "at least from the Jordanian Government", could be found as it was funded by the British government. ${ }^{100}$

\section{(ccc) Finding: No Violation of Article 3}

All in all, the ECtHR found that the assurances given by the Jordanian government in the MoU and the agreement concerning Adaleh as a monitoring body removed the real risk of illtreatment of Abu Qatada. Accordingly, they held that his deportation to Jordan with diplomatic assurance would not be in violation of art 3 of the Convention.

\section{(bb) Evaluation of the Concrete Reasoning}

The overall line of reasoning of the ECtHR is clear. The court underlines with its in-depth context-based analysis of the MoU in question the importance of having case-by-case decisions in order to find if a DWA is compatible with art 3 of the Convention. In the concrete reasoning, the factor of having an effective monitoring body to ensure that Jordan would abide by the concrete MoU was crucial.

However, some aspects of the concrete reasoning remain unclear and controversial:

Firstly, it is questionable in how far the Adaleh Centre can be really seen as an independent body since it is funded by the sending state, the UK. In how far can it then be an NGO? The Adaleh Centre might be influenced by the UK which itself is not committed to watching the

\footnotetext{
94 At [194].

95 At [195].

96 Ibid.

${ }^{97}$ See [197-204].

98 At [199].

${ }^{99}$ At [203-204].

${ }^{100}$ At [203].
} 
treatment of Abu Qatada since art 3 does not involve adjudicating on the receiving country's compliance with the Convention.

The Jordan Times reported in September 2013 that Abu Qatada's lawyer filed a complaint at the Adaleh Centre as Abu Qatada's access to legal advice was restricted. ${ }^{101}$ Therefore, it seems that his access to legal advice which was seen as a "fundamental safeguard against illtreatment" by the ECtHR is not sufficiently protected through the MoU and the monitoring agreements.

Secondly, a very controversial aspect of the court's concrete reasoning is its ruling that the system of systematical torture in Jordan does not preclude the UK government from relying on the agreement. Some scholars state that this aspect of the judgment appears to be inconsistent with the position of the UN Committee against Torture bearing in mind that Jordan's practice constantly violates its obligations under various binding international instruments. ${ }^{102}$

\section{(b) General Principles}

\section{(aa) Judgment of the ECtHR}

In its general approach, the court acknowledged deportation of non-national terrorist suspects to their home country as a legitimate means of fighting against terrorism if they pose a threat to the national security. ${ }^{103}$ However, if the foreign terrorist suspect faces a real risk of being subjected to torture in the receiving state, "article 3 implies an obligation not to deport the person in question to that country". 104

The court stated that in order to determine the real risk consideration would have to be given to the general human rights situation in the receiving country as well as to the particular characteristics of the applicant. ${ }^{105}$ Furthermore, as a third factor, assurances should be taken into account when obtained from the receiving state. ${ }^{106}$ Regardless of the propriety of seeking assurances, the judges see their task with regard to art 3 of the Convention in examining "whether the assurances obtained in a particular case are sufficient to remove any real risk of ill-treatment". 107

This proves that the court is not convinced that diplomatic assurances automatically provide for a sufficient protection but need scrutiny. Thus, the ECtHR stated that they could only be seen as sufficient when they provide for a sufficient guarantee of protection against the risk of

\footnotetext{
${ }^{101}$ Khetam Malkawi “Abu Qatada will not submit new Bail Request - Lawyer” (30 September 2013) The Jordan Times <www.jordantimes.com>.

${ }^{102}$ Conor McCarthy "Diplomatic Assurances, Torture and Extradition: The Case of Othman (Abu Qatada) v. the United Kingdom” (18 January 2012) EJIL:Talk! <www.ejiltalk.org> at 2.

${ }^{103}$ Abu Qatada $v$ the UK, above n 2, at [183-184].

104 At [184].

105 At [187].

${ }^{106}$ Ibid.

107 At [186].
} 
ill-treatment in their practical applications. ${ }^{108}$ The weight to be given to these assurances depends on the particular circumstances of each case. ${ }^{109}$

The court stated that in some "rare cases"110 "the general human rights situation in the receiving state excludes accepting any assurances whatsoever". ${ }^{111}$ In all the other cases, the court takes a two step-assessment approach, assessing the following: ${ }^{12}$

- the quality of the assurances given

- whether, in light of the receiving State's practices, they can be relied upon

With regard to this assessment process, the court listed eleven factors, to which it would have regard "inter alia". ${ }^{113}$ Some of these relevant factors are ${ }^{114}$ :

- the specificity of the assurance

- the person who has given the assurance and whether that person can bind the receiving state

- the form of bilateral relations between the receiving and the sending states

- whether diplomatic or other monitoring mechanisms can objectively verify that the receiving state will abide by the assurance

\section{(bb) Evaluation of the General Principles}

Overall, the general principles laid down by the court could function as a guideline for the UK and other countries with a DWA policy to conclude diplomatic assurances which would more likely withstand judicial scrutiny. ${ }^{115}$

However, it remains unclear what weight should be given to the eleven factors brought up by the court and how they are intended to interfere with each other. Particularly in the UK, the concern was raised whether the ECtHR would uphold diplomatic assurances consistent with art 3 of the Convention where no independent monitoring arrangement has been concluded, since the House of Lords has ruled ${ }^{116}$ that this was possible. ${ }^{117}$ In the particular reasoning of Abu Qatada's case, however, the monitoring arrangement has played an immense role for the ECtHR's ruling.

\footnotetext{
108 At [187].

109 Ibid.

110 At [188].

111 Ibid.

112 At [189].

${ }^{113}$ Ibid.

114 See [189].

115 See Ben Middleton "European Court of Human Rights: Assuring Deportation of Terrorist Suspects" (2012) 76 J Crim L 213 at 216.

${ }^{116}$ See e.g. RB (Algeria) and Another v Secretary of State for the Home Department [2009] UKHL 10, [2009] 2 WLR 512 at [193].

${ }^{117}$ Ben Middleton, above n 115, at 217.
} 
Furthermore, as the court underlined that it would give consideration to these factors only "inter alia" it is likely that in other cases other factors that may not have been listed here become crucial, like the length of duration of the assurances with regard to the application to a specific person.

Besides, further qualification will be needed to determine the "rare cases" in which the general human rights situation is so bad that no assurances can be relied upon. The statement that in some cases the assurances cannot be accepted to remove any real risk of torture is reasonable. However, the term "rare cases" is too vague and requires further explanation. If Jordan's human rights situation, which can be described as poor with regard to its high record of "widespread" practice of torture does not fall under this scope, what other country's human rights situation does?

$2 \quad$ Article 6: Right to a Fair Trial

(a) Concrete Reasoning

(aa) Judgment of the ECtHR

Abu Qatada has alleged a breach of art 6 of the Convention, claiming that his retrial would amount to a flagrant denial of justice for various factors, including the absence of a lawyer in interrogation, the consequences of his notoriety and the composition of the State Security Court and the admission of torture evidence in his retrial. The court identified the factor of admitting the use of torture evidence in his retrial as the "central issue" with regard to a possible violation of art $6 .^{118}$

In its assessment, the court took a three-step approach ${ }^{119}$ :

- if there had been evidence obtained by torture against the applicant

- whether there could be found a real risk of the admission of torture evidence

- whether a flagrant denial of justice arose in the case where there was a real risk of the admission of torture evidence

Whereas the court found it indisputable that in Abu Qatada's case there had been evidence obtained by torture against the applicant with regard to the obtainment of the two witnesses' statements against Abu Qatada, the other two factors were identified as more contestable and therefore examined in more depth.

\section{(aaa) Real Risk of the Admission of Torture Evidence}

First of all the court stated that there was no higher burden of proof for Abu Qatada so that a real risk of the admission of torture evidence would suffice. ${ }^{120}$ Especially the fact that it was

\footnotetext{
${ }^{118}$ Abu Qatada v the UK, above n 2, at [268].

119 See [269-271].

${ }^{120}$ See $[272-273 ; 276]$.
} 
difficult to prove allegations of torture in a criminal justice system "which is complicit in the very practices which it exists to prevent" would make it inappropriate to demand a high standard of proof. ${ }^{121}$ Consequently, the court refused to apply the "balance of probabilities test" used by the House of Lords in Belmarsh, arguing that it was an inappropriate means. ${ }^{122}$

Although the court stated that the use of torture evidence was prohibited under Jordanian law, it underlined its doubts about the real practical value of this legal prohibition. ${ }^{123}$ According to the judges, both torture in Jordan and the use of torture evidence by Jordanian courts is widespread. $^{124}$

With regard to the evidence in question, the two statements of the witnesses which were obtained by torture, the judges held that although Abu Qatada legally had a right to challenge the admissibility of the torture evidence, this would be difficult: not only because of the number of years passed after these events, which would hinder this right from being effective, but also because of the fact that the Jordanian State Security court was more likely to reject such a claim. ${ }^{125}$ According to the ECtHR, the Jordanian State Security Court had shown little readiness to use its power to carefully scrutinise potentially tainted evidence due to its "lack of independence" from the General Intelligence Directorate and the Public Prosecutor. ${ }^{126}$ Therefore, a real risk of the admission of torture evidence in his retrial was given. ${ }^{127}$

\section{(bbb) Flagrant Denial of Justice}

According to the judges, "a flagrant denial of justice will arise when evidence obtained by torture is admitted in criminal proceedings". ${ }^{128}$ With regard to the high probability that torture evidence would be admitted in Abu Qatada's retrial, the ECtHR held that this real risk would amount to a flagrant denial of justice. ${ }^{129}$

In the following, the court contrasted this finding to its judgment in Mamtkulov and Askarov $v$ Turkey, where no violation of art 6 had been found. They argued that in contrast to the aforementioned judgment, where a complaint of a violation of art 6 was merely of a "general and unspecific nature" 130 , this time the complaint of a violation of art 6 was a "sustained and well-founded attack on a State Security Court system that will try him in breach of one of the most fundamental norms of international criminal justice, the prohibition on the use of evidence obtained by torture." 131 Thus, the ECtHR found that the burden of proof was met in

\footnotetext{
121 At [276].

122 At [274].

123 At [278].

124 At [277].

125 At [279].

126 At [278].

127 See [278-280].

128 At [282].

${ }^{129}$ Ibid.

${ }^{130}$ At [284].

131 At [285].
} 
Abu Qatada's case, demonstrating a real risk of a flagrant denial of justice in case of his deportation to Jordan. ${ }^{132}$

\section{(ccc) Finding: Violation of Article 6}

All in all, the court held that Abu Qatada's deportation to Jordan would violate art 6 of the Convention because of the real risk that torture evidence would be admitted in his retrial. ${ }^{133}$

The concrete reasoning of the ECtHR, with regard to its finding on art 6 , is presented in a striking and clear manner, focused on the question if there would be a real risk of the admission of torture evidence in Abu Qatada's retrial if he was deported.

It should be welcomed that the ECtHR stated that the real risk of the admission of torture evidence in Abu Qatada's retrial would suffice in order to proof a flagrant denial of justice due to its difficulties in proving allegations of torture in Jordan's criminal system. By explicitly rejecting the House of Lord's "balance of probabilities test" with regard to art 6 as an inappropriate means, a clear stance was taken.

However, it must be criticised that the court did not comment on the role of diplomatic assurances in this context despite the fact, that in the present case, the MoU between Jordan and the UK did contain a provision concerning the right to a fair trial of returning persons. ${ }^{134}$ Unlike with regard to art 3, the ECtHR failed to examine in its assessment concerning art 6, if assurances given by Jordan could remove the real risk of the admission of torture evidence. ${ }^{135}$

This last evaluation can be supported by the fact that the Court of Appeal, in contrast to the ECtHR, did refer to the reliability on assurances in the context of art 6. The Court of Appeal stated that a "high degree of assurance" was required to remove the real risk that torture evidence would not be relied upon in a trial in the receiving state. ${ }^{136}$ However, in the Court of Appeal's point of view, the assurance given by the Jordanian government could not be conceived as such assurances with regard to art $6 .{ }^{137}$

\footnotetext{
132 Ibid.

${ }^{133}$ Abu Qatada's other complaints under this article (concerning the absence of a lawyer in interrogation, the prejudicial consequences of his notoriety, the composition of the State Security Court or the aggravating nature of the length of sentence he would face if convicted) were not further examined by the court, see [286].

${ }^{134}$ See MoU UK-Jordan, above n 24, para 6. Note that the ECtHR referred to this paragraph of the MoU once in its judgment, see Abu Qatada v the UK, above n 2, at [78].

${ }^{135}$ The only justified reason for the ECtHR for not having raised this question would be that due to the burden of proof, no statements of the government were put forward with regard the role of assurances in the context of art 6.

${ }^{136}$ Othman $v$ SSHD, above $\mathrm{n}$ 83, at [49]. This high threshold was not met according to the judges in the present case, see [52].

${ }^{137}$ Abu Qatada v the UK, above $\mathrm{n}$ 2, at [52].
} 
In its general approach with regard to art 6 of the Convention, the court outlined its general principles concerning the "flagrant denial of justice test" and made concrete statements why the admission of evidence obtained by torture amounts to a flagrant denial of justice.

The court at first defined the "flagrant denial of justice test" as being "synonymous with a trial which is manifestly contrary to the provisions of article 6 or the principles embodied therein". ${ }^{138}$ It stated that this definition might be vague and needed further determination. However, referring to the fact that the court itself had never found a violation of art 6 in deportation cases, the judges underlined the high threshold of this test as a "stringent test of unfairness", which required more than "mere irregularities or lack of safeguards in the trial procedures". ${ }^{139}$ Consequently, according to the judges, a flagrant denial of justice requires a breach of the fair trial principles, being so fundamental that it amounts to a "nullification or destruction of the very essence, of the right guaranteed by that article." ${ }^{140}$ If this threshold is met has to be decided on the same standard and burden of proof principles that apply to article 3 deportation cases, the mutatis mutandis principle ${ }^{141}$.

Having outlined four forms of unfairness in preceding cases which amounted to a flagrant denial of justice, ${ }^{142}$ the judges raised the question if the admission of evidence obtained by torture was a fifth form falling into this category. ${ }^{143}$ Based on international law and common law, they considered that this was the case for the following three reasons: ${ }^{144}$

- the use of torture evidence destroys the integrity of the trial process and is therefore against the rule of law

- torture evidence is intrinsically unreliable

- the morally reprehensible conduct of torture should not be indirectly legitimated contrary to the legislative intent of art 3

In an obiter dictum, the ECtHR stated that it did not exclude that the use of evidence resulting from other, less serious forms of ill-treatment than torture could also amount to a flagrant denial of justice. ${ }^{145}$

With regard to a breach of art 6 , the judges emphasised the fundamental difference between the admission of torture evidence and other defects in the trial process or the composition of

\footnotetext{
138 At [259].

139 At [260].

140 Ibid.

${ }^{141}$ According to which it is for the applicant to prove that there are substantial grounds for believing that there is a real risk of being subjected to a flagrant denial of justice and it is for the defendant (the sending government) to dispel any doubts about it, see [261].

142 See [259].

143 At [263].

144 At [264].

145 Ibid.
} 
the trial court. ${ }^{146}$ The court stated that the admission of torture evidence was not only contrary to the right to a fair trial under the convention, but also to the right to a fair trial under most international covenants like art 15 UNCAT. ${ }^{147}$

For the foregoing reasons, the admission of torture evidence would "make the whole trial not only immoral and illegal, but also entirely unreliable in its outcome". ${ }^{148}$

\section{(bb) Evaluation of the General Principles}

Overall, the general principles laid down by the ECtHR should be welcomed as they clarify why art 6 is relevant in deportation cases.

On an abstract level, by referring to the flagrant denial of justice test as a "stringent test of unfairness" the court has confirmed the high threshold of a violation of art 6 in this context, which can be seen in line with the underlying intention in its former Soering $v$ the UK judgment. The court's distinction drawn between specific and concrete fair trial complaints on the one hand and general and not concrete fair trial complaints on the other hand can provide further guidance as to the meaning of the flagrant of denial of justice test. ${ }^{149}$

On a concrete level, the ECtHR clearly stated that the real risk of the admissibility of torture evidence amounts to a flagrant denial of justice and therefore emphasised that torture evidence destroys the integrity of the trial process and is therefore against the rule of law. Although this clear statement is highly valuable, further clarification is needed concerning the question if or under which circumstances diplomatic assurances may remove the real risk of using evidence obtained by torture.

Besides, the obiter dictum of the ECtHR, stating that a less serious form than torture evidence may also suffice to amount to a flagrant denial of justice, should be considered in the states which use the DWA policy. This statement legitimately underlines the will of the ECtHR to protect the core values of the Convention in transnational situations. ${ }^{150}$

In short, although the court's ruling on art 6 leads to further questions as to the role diplomatic assurances can play in removing the real risk of torture admission, it is highly valuable in that it has further developed the jurisprudence on the general question of what constitutes a "flagrant denial of justice". ${ }^{151}$

\footnotetext{
146 At [265].

147 At [266-267].

148 At [267].

${ }^{149}$ Ben Middleton, above n 115, at 214.

150 John Vervaele "Extraordinary Rendition and the Security Paradigm" Union of Jurists of Romania LR 3 (2013) 1 at 14.

${ }^{151}$ Conor Mc Carthy, above n 102, at 3.
} 
Apart from its findings on arts 3 and 6 the ECtHR held that there had been neither a violation of art 13 in conjunction with art 3 nor of art 5 of the Convention.

With regard to art 13 of the Convention, the right to an effective remedy, the court dismissed Abu Qatada's complaint that SIAC's procedure of having heard closed evidence in order to establish the effectiveness of assurances by the Jordanian government was incompatible with his right to an effective remedy. The judges found that his complaint was linked to his substantive complaint under art 3 and therefore admissible. ${ }^{152}$ However, they stated that there was no "enhanced requirement for transparency and procedural fairness where assurances are being relied upon" "153, thus finding that SIAC's procedures which included the disclosure of secret evidence to special advocates satisfied the requirements of art 13 of the Convention. ${ }^{154}$

With regard to art 5 of the Convention, the right to liberty and security, the ECtHR held that the real risk of being in incommunicando detention for up to fifty days before Abu Qatada's retrial would not constitute a flagrant breach of this article. ${ }^{155}$ Regardless of this concrete finding, it must be noted that unlike the ECtHR's approach in Tomic $v$ the UK, the court articulated for the first time explicitly that art 5 could apply in expulsion cases. ${ }^{156}$ Comparable to art 6 a flagrant breach of art 5 required a high threshold, which, according to the judges, would exemplarily be met in the following cases: ${ }^{157}$

- if the receiving state arbitrarily detained an applicant for many years without any intention of bringing him or her to trial

- if the applicant was be at risk of being imprisoned for a substantial period in the receiving state, having previously been convicted after a flagrantly unfair trial.

Whereas the finding on art 13 is in line with former judgments of the ECtHR and vindicates SIAC's function in the $\mathrm{UK}^{158}$, the court's general comments on a violation of art 5 can be seen as a new approach of the court and require national governments' consideration for future DWA cases ${ }^{159}$.

\section{Implications of the ECtHR's Judgment in Abu Qatada}

2012's decision of the ECtHR in Abu Qatada $v$ the UK shows that the ECtHR is walking a difficult tightrope in the field of the interplay of the DWA policy and the Convention: whereas they found diplomatic assurances to be a possible means of removing the real risk of

\footnotetext{
${ }^{152}$ Abu Qatada v the UK, above n 2, at [214].

153 At [219].

${ }^{154}$ See [220-225].

155 See [234-235].

${ }^{156}$ See [233].

157 Ibid.

${ }^{158}$ Ben Middleton, above n 115, at 218.

${ }^{159}$ At 217.
} 
ill-treatment regardless of a widespread and routine system of torture in the receiving state, the itself system of torture is seen as a relevant factor for finding a breach of art $6 .{ }^{160}$

This somewhat inconsistent judgment has led to controversial discussions among Member States of the European Council and scholars as to whether it has strengthened or weakened the non-refoulement principle under the Convention. On the one hand, with regard to art 3 of the Convention the non-refoulement principle has been seen as weakened, for the reason that a low threshold for assurances now seems to be sufficient to avoid breaching the nonrefoulement principle. ${ }^{161}$ On the other hand, it has been argued that the scope of the nonrefoulement principle has been extended by this judgment, by the judges including the consideration of a risk of a flagrant denial of justice under art 6 of the Convention. ${ }^{162}$

Both viewpoints can be justified. However, further clarification is required as to what threshold is necessary for diplomatic assurances to avoid a breach of art 6 of the Convention. If the ECtHR sets the same low threshold for assurances with regard to art 6 as for assurances with regard to art 3, "the extension of the non-refoulement to include the risk of a flagrant denial of justice will be rather symbolic". ${ }^{163}$ Time will tell.

\section{B Shift in Jurisprudence?}

With regard to the ECtHR's rulings both on art 3, finding diplomatic assurances for the first time sufficient in terms of removing any real risk of extra-territorial torture, and on art 6 , finding for the first time, after 22 years, a flagrant denial of justice in a DWA case, it must be examined if the aforementioned judgment has contributed to a shift from the former jurisprudence to a new one.

Recently, the ECtHR has dealt with some noteworthy cases of extraditions and deportations, shedding light on the question whether its decision in Abu Qatada $v$ the $U K$ has marked a shift in jurisprudence:

Firstly, in the extradition case Rafaa $v$ France ${ }^{164}$, the ECtHR explicitly re-approved the absolute nature of art 3 in extra-territorial cases in line with the Soering $v$ the UK and Saadiv Italy judgments by denying any kind of balancing act. ${ }^{165}$

\footnotetext{
${ }^{160}$ Evelyne Sturm "Diplomatische Zusicherungen - Schwierige Gratwanderung des Europäischen Gerichtshofs für Menschenrechte" (2 May 2012) Schweizerisches Kompetenzzentrum für Menschenrechte (SKMR) $<$ www.skmr.ch>.

${ }^{161}$ Christopher Michaelsen "The Renaissance of Non-Refoulement? The Othman (Abu Qatada) Decision of the European Court of Human Rights“ (2012) 61 ICLQ 750 at 764.

162 John Vervaele "Extraordinary Rendition and the Security Paradigm" Union of Jurists of Romania LR 3

(2013) 1 at 13; Christopher Michaelsen, above n 161, at 764.

${ }^{163}$ Christopher Michaelsen, above n 161, at 765.

${ }^{164}$ Rafaa v France (25393/10) Section V, ECHR 20 May 2013.

165 Ibid, at [40].
} 
Secondly, in the deportation case of Labsi $v$ Slovakia ${ }^{166}$ the court dealt with the interplay of the DWA policy and the Convention. In this case, the ECtHR found that the practical application of the diplomatic assurances given Algeria to Slovakia were insufficient to remove the real risk of ill-treatment in Algeria ${ }^{167}$, the deportation thus breaching art 3 of the Convention. ${ }^{168}$ By referring to six of the eleven factors listed in Abu Qatada, ${ }^{169}$ the judges identified as a relevant factor that "the assurances given could not be objectively verified through diplomatic or other monitoring mechanisms". ${ }^{170}$ Thus, referring to the general principles laid down in Abu Qatada, the ECtHR seems to uphold a high threshold concerning the sufficiency of a diplomatic assurance for removing the real risk of torture or inhumane treatment.

Thirdly, in the extraordinary rendition case of El-Masri v Macedonia ${ }^{171}$ the ECtHR reiterated the finding in Abu Qatada that "a Contracting State would be in violation of art 5 of the Convention if it removed an applicant to a State where he or she was at real risk of a flagrant breach of that article". ${ }^{172}$ This aforementioned case can serve as an example of the tendancy of the court to be more likely to find breaches of art 5 and 6 of the Convention in DWA cases due to its judgment in Abu Qatada.

Therefore, the judgment of Abu Qatada has rather modified than reformed the jurisprudence of the ECtHR. The "restrictive stance" of the ECtHR with regard to diplomatic assurances continues to be upheld after Abu Qatada $v$ the $U K .{ }^{173}$

\section{Conclusion}

The decision of the ECtHR in Abu Qatada is a remarkable judgment concerning the interplay of the DWA policy and the Convention and could function as a guideline for governments which use the DWA policy, the politicians having to bear in mind the following principles laid down by the court:

Firstly, with regard to the absolute prohibition of torture under art 3 of the Convention, the court clearly expressed that diplomatic assurances are an "acceptable way to allay the risk of torture". ${ }^{174}$ It has further determined the prerequisites of a diplomatic assurance to be sufficient to remove any real risk of torture or ill-treatment with respect to a person to be deported. The court outlined in that decision that the practical application of the diplomatic

\footnotetext{
${ }^{166}$ Labsi v Slovakia (33809/08) Section III, ECHR 15 May 2012 (Labsi v Slovakia).

167 At [131].

${ }^{168}$ In addition, the ECtHR found violations of art 13 and 34 of the Convention.

${ }^{169}$ Labsi $v$ Slovakia, above n 166, at [120], including e.g. the monitoring factor but not the factor of the strength of bilateral ties between the states.

${ }^{170}$ At [130].

${ }^{171}$ El-Masri v the Former Yugoslav Republic of Macedonia (2013) 57 EHRR 25 (Grand Chamber, ECHR) (ElMasri v Macedonia).

172 At [239].

${ }^{173}$ Harlan Grant Cohen, above n 5, at 286. Contrast Marc Bossuyt "The Court of Strasbourg Acting as an Asylum Court" (2012) 8 ECLR 203 at 225, who characterises the Abu Qatada judgment concerning the stance towards diplomatic assurances as a "striking exception".

${ }^{174}$ (Case Comment) "Deportation: Deportation of Foreign National - Safety on Return - Othman v United Kingdom (8139/09)" (2012) 3 EHRLR 339 at 343.
} 
assurance was of particular importance and listed eleven factors "inter alia" to be considered. However, further clarification is needed in terms of the weight to be given to the eleven factors brought up by the court, particularly with regard to the question in how far a monitoring body is mandatory as to the reliability of a diplomatic assurance.

Secondly, the statement that the admission of torture evidence amounts to a flagrant denial of justice and therefore breaches art 6 of the Convention is an important clarification concerning the flagrant denial of justice test. In how far diplomatic assurances can remove real risks which amount to a flagrant denial of justice under relevant relative Convention Rights like art 5 or 6 is a crucial point, which needs further clarification.

On the whole, the Court's judgment is valuable for two reasons: First of all, it acknowledges the DWA policy as a legitimate means of the governments of the Council of Europe to treat non-national terrorist suspects. In addition, it sheds light on the question under which circumstances deportation on the basis of diplomatic assurances against torture and other human rights violations may be permissible under the Convention.

The court thus has both confirmed and partly modified its former jurisprudence and legitimately fulfilled its most important function, "the export of sound democratic values to all parts of Europe and indeed beyond." 175

To conclude, this judgment taken into account, the counter terrorism means of deporting a non-national terrorist suspect with diplomatic assurances seems to be compatible with the Convention if the diplomatic assurances given guarantee a sufficient protection of the human rights of the transferee, which due to the uncertain effects of the DWA policy, still has to be decided on a case-by-case basis.

175 David Anderson "Shielding the Compass: How to Fight Terrorism without Defeating the Law" (2013) 3 EHRLR 233 at 246. 
BIBLIOGRAPHY

\section{PRIMARY SOURCES}

\section{A Legislation and Parliamentary Material}

Immigration Act 1971 (UK).

(17 April 2012) 543 UKPD (HC).

(8 July 2013) 566 UKPD (HC).

\section{B Conventions and Covenants}

\section{$1 \quad$ International Conventions and Covenants}

1951 Convention Relating to the Status of Refugees 189 UNTS 137 (adopted 28 July 1951, entered into force 22 April 1954).

International Covenant on Civil and Political Rights 999 UNTS 171 and 1057 UNTS 407 (opened for signature 16 December 1966, entered into force 23 March 1976).

\section{$2 \quad$ European Conventions}

Convention for the Protection of Human Rights and Fundamental Freedoms [1950] COETS 1 (adopted 4 November 1950, entered into force 3 September 1953).

\section{Cases}

\section{$1 \quad$ Europe}

A v the Netherlands (4900/06) Section III, ECHR 20 July 2010.

Baysakov and Others v Ukraine (54131/08) Section V, ECHR 18 February 2010.

Chahal $v$ the United Kingdom (1996) 23 EHRR 413 (ECHR).

$D v$ the United Kingdom (1997) 24 EHRR 423 (ECHR).

El-Masri v the Former Yugoslav Republic of Macedonia (2013) 57 EHRR 25 (Grand Chamber, ECHR).

H.N. v Sweden (30720/09) Section V, ECHR 15 May 2012.

Labsi v Slovakia (33809/08) Section III, ECHR 15 May 2012.

Mamatkulov and Askalov v Turkey (2005) 41 EHRR 2 (Grand Chamber, ECHR). 
$N v$ Finland (2005) 43 EHRR 12 (Section IV, ECHR).

Othman (Abu Qatada) v the United Kingdom (2012) 55 EHRR 1 (Section IV, ECHR).

Rafaa v France (25393/10) Section V, ECHR 20 May 2013.

Saadi v Italy (2008) 49 EHRR 730 (Grand Chamber, ECHR).

Soering $v$ the United Kingdom (1989) 11 EHRR 439 (ECHR).

Tomic $v$ the United Kingdom (17873/03) Section IV, ECHR 14 October 2003.

\section{$2 \quad U K$}

$A(F C)$ and Others (FC) v the Secretary of State for the Home Department [2004] UKHL 56, [2005] 2 WLR 87.

Omar Othman (aka Abu Qatada) v Secretary of State fort he Home Department, [2007] UKSIAC 15/2005, 26 February 2007.

Othman (Jordan) v Secretary of State for the Home Department [2008] EWCA Civ 290, [2008] 3 WLR 798.

RB (Algeria) and Another $v$ Secretary of State for the Home Department [2009] UKHL 10, [2009] 2 WLR 512.

\section{SECONDARY SOURCES}

\section{A Texts}

Kent Roach Comparative Counter-Terrorism (Cambridge University Press, New York, 2011).

\section{B Journal Articles}

David Anderson "Shielding the Compass: How to Fight Terrorism without Defeating the Law" (2013) 3 EHRLR 233.

Marc Bossuyt "The Court of Strasbourg Acting as an Asylum Court" (2012) 8 ECLR 203.

(Case Comment) "Deportation: Deportation of Foreign National - Safety on Return - Othman v United Kingdom (8139/09)" (2012) 3 EHRLR 339.

Harlan Grant Cohen “International Law’s Erie Moment“ (2013) 34 Mich J Int’1 L 249.

Katherine Hawkins "The Promises of Torturers: Diplomatic Assurances and the Legality of 'Rendition"” (2006) 20 Geo Immigr LJ 213.

Kate Jones "Deportations with Assurances: Addressing Key Criticisms" (2008) 57 ICLQ 183. 
Martin Jones "Lies, Damned Lies and Diplomatic Assurances: The Misuse of Dimplomatic Assurances in Removal Proceedings" (2006) 8 Eur J Migration \& L 9.

Conor McCarthy "Diplomatic Assurances, Torture and Extradition: The Case of Othman (Abu Qatada) v. the United Kingdom” (18 January 2012) EJIL:Talk! <www.ejiltalk.org>.

Christopher Michaelsen “The Renaissance of Non-Refoulement? The Othman (Abu Qatada) Decision of the European Court of Human Rights“ (2012) 61 ICLQ 750.

Ben Middleton "Deporting Terrorist Suspects with Assurances: Lessons from the United Kingdom” (2012) 12 Conn Pub Int LJ 127.

Ben Middleton "European Court of Human Rights: Assuring Deportation of Terrorist Suspects" (2012) 76 J Crim L 213.

Gregor Noll "Diplomatic Assurances and the Silence of Human Rights Law" (2006) 7 MJIL 104.

Lena Skoglund "Diplomatic Assurances Against Torture - An Effective Strategy?: A Review of Jurisprudence and Examination of the Arguments" (2008) 77 Nordic J Int'1 L 319.

Evelyne Sturm "Diplomatische Zusicherungen - Schwierige Gratwanderung des Europäischen Gerichtshofs für Menschenrechte" (2 May 2012) Schweizerisches Kompetenzzentrum für Menschenrechte (SKMR) <www.skmr.ch>.

Jennifer Tooze "Deportation with Assurances: the Approach of the UK Courts" [2010] P.L. 362.

Bibi van Ginkel and Federico Rojas "Use of Diplomatic Assurances in Terrorism-related Cases: In Search of a Balance Between Security Concerns and Human Rights Obligations“ (2011) ICCT <www.icct.nl> .

John Vervaele "Extraordinary Rendition and the Security Paradigm" Union of Jurists of Romania LR 3 (2013) 1.

Clive Walker “The Treatment of Foreign Terror Suspects” (2007) 70 Mod L Rev 427.

\section{Essays in Books}

Cornelis (Kees) Wouters "Reconciling National Security and Non-Refoulement: Exceptions, Exclusion, and Diplomatic Assurances" in Ana Maria Salinas de Frias, Kathja LH Samuel and Nigel D White (ed) Counter-Terrorism: International Law and Practice (Oxford University Press, Oxford; 2012) 579.

\section{Theses}

Frank Seier "Diplomatic Assurances Against Torture: Impermissible Inter Se Modifications of Erga Omnes Obligations" (LLM Thesis, University of Toronto, 2008). 
E Internet Resources

<www.amnesty.org>

<www.coe.int $>$.

<www.echr.coe.int $>$.

$\langle$ www.gov.uk>.

<www.hrw.org>

<www.jordantimes.com>.

<www.wcd.coe.int $>$. 